\title{
Mineral Composition of Red Clover under Rhizobium Inoculation and Lime Application in Acid Soil
}

\author{
Olivera STAJKOVIĆ-SRBINOVIĆ*, Dušica DELIĆ, Nataša RASULIĆ, \\ Dragan ČAKMAK, Djordje KUZMANOVIĆ, Biljana SIKIRIĆ \\ InstituteofSoilScience,TeodoraDrajzera 7,11000Belgrade,Serbia;oliverastajkovic@yahoo.com ("correspondingauthor); vukmirdusica@yahoo.com; \\ nrasuli@@yahoo.com;dcakmak@yahoo.com;djonkuz@yahoo.com;biljana-s@sbb.rs
}

\begin{abstract}
In the present study the effects of Rhizobium inoculation and lime application on the mineral composition ( $\mathrm{N}, \mathrm{P}, \mathrm{K}, \mathrm{Ca}, \mathrm{Mg}, \mathrm{Fe}, \mathrm{Mn}, \mathrm{Cu}, \mathrm{Zn}$, B) of red clover (Trifolium pratense L.), in very acid soil were evaluated. Inoculation with Rhizobium leguminosarum bv. trifolii significantly increased shoot dry weight (SDW) of red clover plants (three times greater), as well as N, Mg, Fe, Mn and Cu contents in plants compared to the control. Application of lime and Rhizobium together, depending on the lime rate (3,6 or $9 \mathrm{tha}^{-1}$ of lime) and the cut, increased SDW significantly, but decreased the contents of N, P, K, Mg, Mn, Zn and B in plants. Regardless of the changes, in all treatments in both cuts, contents of N, K, Ca, $\mathrm{Mg}, \mathrm{Mn}$ and $\mathrm{Zn}$ in plants were among sufficiency levels (Mg content was elevated in the second cut), while Fe content was mainly high, as well as $\mathrm{Cu}$ (in the second cut). Contents of $\mathrm{P}$ and $\mathrm{B}$ in plants were somewhat lower than sufficiency levels, but above critical level. Therefore, red clover can be grown with satisfactory yield and mineral composition in acid soil with Rhizobium inoculation only, but the application of $\mathrm{P}$ and $\mathrm{B}$ fertilization is desirable.
\end{abstract}

Keywords: macronutrients, micronutrients, Trifolium pratense L., inoculation, yield increase

\section{Introduction}

Red clover (Trifolium pratense L.) is one of the most important perennial forage legumes owing to its high biomass yield and quality of forage (Vasiljević et al., 2010). In addition, it can tolerate soils of poorer quality, slightly higher acidity and shallow soils. Red clover can establish a nitrogen-fixing symbiosis with Rhizobium leguminosarum bv. trifolii and fix atmospheric nitrogen of the benefit to the plant in the wide range of 76-334 $\mathrm{kg} \mathrm{N} \mathrm{ha}^{-1}$ annually (Taylor and Quesenberry, 1996). For red clover, $\mathrm{N}$ values derived from the atmosphere went up above 90\% of the total plant $\mathrm{N}$ (Warembourg et al., 1997; Thilakarathna et al., 2012). Consequently, red clover can satisfy most of its nitrogen needs and also contributes to the incorporation of $\mathrm{N}$ in soil, helping to reduce the application of mineral $\mathrm{N}$ fertilizers. Some studies indicated that rhizobia, besides $\mathrm{N}_{2}$ fixation, may have positive effect on certain macro and micronutrient contents in leguminous plants and soil and overall plant growth (Bambara and Ndakidemi, 2010; Ndakidemi et al., 2011). Rhizobial strains enhanced the uptake of many macro and micronutrients in peanut nodules and seeds (Howell, 1987), soybean (Tairo and Ndakidemi, 2014a,b) and common bean plants (Makoi et al., 2013; Ndakidemi et al., 2011). Inoculating chickpea with Mesorbizobium mediterraneum also increased the levels of K, Ca, Mg, P and $\mathrm{N}$ in plant parts (Peix et al., 2001).
Belane et al. (2014) concluded that rhizobial strains possessing high nitrogen-fixing ability induce mineral accumulation in young cowpea plants (Vigna unguiculata L. Walp.). Rhizobia strains may facilitate the availability and uptake of certain nutrients such as P, Fe, Zn (Jin et al., 2006; Ndakidemi et al., 2011). Mechanisms of rhizobial action include: production of organic acids which convert insoluble phosphorus compounds to more soluble forms, production of siderophores that chelate iron and make it available to the plant, and the production of phytohormones (auxin, etc.) which change root architecture and favour nutrient uptake (Antoun et al., 1998). Therefore the use of rhizobia to increase soil fertility and improve growth and yield of important crops such as red clover could be an important alternative to chemical fertilizers in sustainable agriculture.

Besides nutrient availability, low soil $\mathrm{pH}$ is one of the most limiting factors for plant production. Acid soils take up around one third of the soil worldwide, while in Serbia, around 60\% of arable land is of acid reaction (Sikiric et al., 2011). Soil pH of 5.5 is considered the lower limit for most forage legumes. In acid soil, plant growth was limited due to toxic concentrations of $\mathrm{H}, \mathrm{Al}$, $\mathrm{Mn}$ and Fe and deficiency of N, P, Ca, Mg, B and Mo (Von Uexküll and Mutert, 1995). The sensitivity of legume to acid soil is also the result of soil $\mathrm{pH}$ influence on the rhizobial bacteria. However, some effective $R$. trifolii strains can tolerate quite low 
Table 1. Soil characteristics at the study site

\begin{tabular}{|c|c|c|c|}
\hline Parameter & Value & Parameter & Value \\
\hline $\mathrm{pH} \mathrm{KCl}$ & 4.3 & $\mathrm{P} \mathrm{mg} \mathrm{kg}^{-1}$ & 30.51 \\
\hline $\mathrm{pH} \mathrm{H} \mathrm{H}_{2} \mathrm{O}$ & 5.9 & $\mathrm{~K} \mathrm{mg} \mathrm{kg}^{-1}$ & 143.20 \\
\hline $\mathrm{C}_{\text {org }} \%$ & 2.12 & $\mathrm{Mg} \mathrm{mg} \mathrm{g}^{-1}$ & 260 \\
\hline $\mathrm{N}_{\text {tot }} \%$ & 0.143 & $\mathrm{Cag} \mathrm{kg}{ }^{-1}$ & 1.26 \\
\hline $\mathrm{NH}_{4}^{+}-\mathrm{N} \mathrm{mg} \mathrm{kg}^{-1}$ & 5.25 & & \\
\hline $\mathrm{NO}_{3}-\mathrm{N} \mathrm{mg} \mathrm{kg}^{-1}$ & 15.25 & & \\
\hline
\end{tabular}

soil $\mathrm{pH}$ (4.9) (Lindstrom and Millyniemi, 1987). Red clover grows well on moderately acid soils, but a pH above 6.0 and adequate $\mathrm{Ca}$ is required for maximum yields (Fairey, 1988). Therefore, to obtain high and quality red clover yield, the application of lime is desirable. In contrast, the application of lime causes the decrease of $\mathrm{Al}, \mathrm{Mn}$ and Fe toxic concentrations, but can also result in the lack of certain micronutrients (Fageria et al., 1995).

Although there are some researches showing the potential of Rhizobium inoculation to increase red clover yield in acid soils, little is known about Rhizobium effect on the nutrient accumulation in red clover plants. Therefore, the aim of the this work was to evaluate the effect of Rhizobium inoculation and lime on yield and macro and micronutrient contents $(\mathrm{N}, \mathrm{P}, \mathrm{K}$, $\mathrm{Ca}, \mathrm{Mg}, \mathrm{Fe}, \mathrm{Mn}, \mathrm{Cu}, \mathrm{Zn}, \mathrm{B})$ of red clover grown in an acid soil.

\section{Materials and Methods}

\section{Soil and experiment design}

To set up the experiment, top soil layer $(30 \mathrm{~cm})$ of an acid

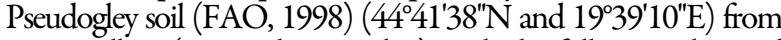
Varna village (near Valjevo, Serbia), with the following chemical characteristics (Table 1) was used. Each pot was filled with $2 \mathrm{~kg}$ of air-dried soil and 20 seeds of red clover were planted, and after two weeks thinned to 10 plants. The experiment was observed for a year, with 6 different treatments and one control with three repetitions: inoculation (R. leguminosarum bv. trifolii strain 459), inoculation and addition of 3, 6 or $9 \mathrm{t} \mathrm{ha}^{-1}$ of $\mathrm{CaCO}_{3}$ and $\mathrm{NPK}_{1 / 2}$ fertilization, inoculation and zeolite application, NPK fertilization without inoculation (NPK), control Ø (no inoculation and no fertilization).

In early spring of 2013, NPK mineral fertilization in amount of $60 \mathrm{kgha}^{-1}, \mathrm{P} 100 \mathrm{kgha}^{-1}$ and $\mathrm{K} 100 \mathrm{kgha}^{-1}$ was performed, or a half of this amount $\left(\mathrm{NPK}_{1 / 2}\right)$ in lime treatments. A month before the experiment was set up, $2 \mathrm{~g}_{\text {pot }}{ }^{-1}$ zeolite (clinoptilolite) (equivalent to $3 \mathrm{t} \mathrm{ha}^{-1}$ ) or $2,4,6 \mathrm{~g}$ pot ${ }^{-1}$ of $\mathrm{CaCO}_{3}$ (equivalent to 3 , 6 or 9 t ha $^{-1}$ of $\mathrm{CaCO}_{3}$ respectively) were added, mixed thoroughly and watered regularly. Zeolite used had following chemical composition: $63.60 \% \mathrm{SiO}_{2}, 11.81 \% \mathrm{Al}_{2} \mathrm{O}_{3}, 1.74 \% \mathrm{Fe}_{2} \mathrm{O}_{3}, 7.35 \%$ $\mathrm{CaO}, 0.68 \% \mathrm{MgO}, 0.40 \% \mathrm{TiO}_{2}, 4.40 \% \mathrm{Na}_{2} \mathrm{O}, 0.169 \% \mathrm{~K}_{2} \mathrm{O}$.

\section{Soil and plant samples analyses}

Plant samples were taken and analysed in two cuts, 9 and 15 weeks after the experiment establishment, while soil samples were analysed 15 weeks after the experiment establishment.

Soil $\mathrm{pH}$ was determined with a glass electrode $\mathrm{pH}$ meter in $1 \mathrm{~N} \mathrm{KCl}$ and in $\mathrm{H}_{2} \mathrm{O}$ (in ratio soil: $\mathrm{KCl}$ or $\mathrm{H}_{2} \mathrm{O}$ 1:2.5). Available $\mathrm{N}$ forms in the soil $\left(\mathrm{NH}_{4}^{+}, \mathrm{NO}_{3}{ }^{-}\right)$were determined by steam distillation method described by Bremner (1965). Available P and $\mathrm{K}$ in soil were determined by the AL-method of EgnerRiehm (Egner $e t a l ., 1960)$. Soil Ca and Mg were extracted by ammonium acetate and determined with a SensAA Dual atomic adsorption spectrophotometer (Dandenong, Australia). Soil organic $\mathrm{C}$ and $\mathrm{N}$ were determined with a elemental $\mathrm{CNS}$ analyser, Vario model EL III (Hanau, Germany). Available forms of Mn, $\mathrm{Fe}, \mathrm{Zn}$ and $\mathrm{Cu}$ in soils were extracted by DTPA (Soltanpour et al, 1996) and determined by plasma emission spectrometry ICAP 6300 ICP (Cambridge, UK). The B contents in soil and plant was determined by colorimetry (curcumin method) after dry digestion (Dible etal., 1954).

For the determination of the plant $\mathrm{K}, \mathrm{P}, \mathrm{Mg}, \mathrm{Ca}, \mathrm{Mn}, \mathrm{Fe}, \mathrm{Zn}$ and $\mathrm{Cu}$, leaves were burned to ash at $550^{\circ} \mathrm{C}$ and acid digestion with $\mathrm{HCl}$ was performed according to Chapman and Pratt (1961). Phosphorus was measured by the colorimetric ammonium vanadate method and $\mathrm{K}$ by flame photometry (Egner et al., 1960). Ca and Mg contents in plant samples were determined by atomic absorption spectroscopy after Chapman and Pratt (1961). Total plant $\mathrm{N}$ was determined with elemental $\mathrm{CNS}$ analyzer. $\mathrm{Mn}, \mathrm{Fe}, \mathrm{Zn}$ and $\mathrm{Cu}$ contents in plants were determined by ICAP 6300 ICP.

\section{Statistical analysis}

The effect of the treatments was evaluated using analysis of variance (SPSS 16.0 program, 2007), and significant differences between means were tested by Duncan's multiple range test.

\section{Results}

\section{Changes in soil properties}

Rhizobium inoculation did not significantly change soil $\mathrm{pH}\left(\mathrm{H}_{2} \mathrm{O}\right)$ or content of available macronutrients $\mathrm{P}, \mathrm{K}, \mathrm{Ca}$ and $\mathrm{Mg}$ in soil (Table 2). The application of lime increased soil $\mathrm{pH}$ significantly and the optimal soil $\mathrm{pH}$ range of 6-6.5 for red clover cultivation (Fairey, 1988) was reached with 3 tha ${ }^{-1}$ of lime. Soil was at the medium level of total $\mathrm{N}$ supply in all treatments and there were no differences between treatments. In lime treatments $\mathrm{NH}_{4}^{+}$ increased ( $1 / 2 \mathrm{NPK}$ was added in these treatments), while $\mathrm{NO}_{3}$. concentration decreased in all treatments (except NPK) (Table 2). Lime application increased initially very low soil $\mathrm{P}$ content to the medium, but did not change medium content of available $\mathrm{K}$ in soil. After liming, the Ca content in soil increased from medium to high, while high available $\mathrm{Mg}$ content decreased significantly only with $9 \mathrm{t} \mathrm{ha}{ }^{-1}$ of lime ( $\mathrm{Mg}$ content still remained high). In the treatment with zeolite, $\mathrm{pH}, \mathrm{K}$ and $\mathrm{Ca}$ contents in soil increased significantly, while Mg content decreased.

In this research, high content of micronutrients $\mathrm{Fe}, \mathrm{Mn}, \mathrm{Cu}$ and $\mathrm{Zn}$ (medium) in control soil did not change significantly under Rhizobium inoculation, while low B content increased to the medium level. Lime application decreased $\mathrm{Fe}, \mathrm{Mn}, \mathrm{Cu}$ (except $\left.9 \mathrm{tha}^{-1}\right), \mathrm{Zn}$ and $\mathrm{B}$ contents in soil, but $\mathrm{Fe}$ and $\mathrm{Cu}$ contents were still high. In the treatment with zeolite, $\mathrm{Fe}, \mathrm{Mn}$, and $\mathrm{Zn}$ decreased in soil, while B increased.

\section{Yield of red clover}

Inoculation with Rhizobium increased shoot dry weight (SDW), of red clover plants in both cuts in respect to the control $\varnothing$ (Table 4). In the second cut, SDW was three times greater compared to the control and did not differ from the treatments with $3 \mathrm{t} \mathrm{ha}^{-1}$ of lime, nor with zeolite, but was higher than in NPK treatment. All lime rates together with inoculation increased SDW in both cuts due to an immediate rise in $\mathrm{pH}$ of very acid soil (Table 2), with no extra effect of the highest lime rate $9 \mathrm{t} \mathrm{ha}^{-1}$ on SDW increase or soil $\mathrm{pH}$. The maximum yield in the first cut was obtained with the application of $3 \mathrm{tha}^{-1}$ lime, while in the second cut it was achieved with $6 \mathrm{th}^{-1}$ lime. 
Table 2. Effects of inoculation and lime on macronutrient contents in soil

\begin{tabular}{|c|c|c|c|c|c|c|c|c|c|}
\hline \multirow{2}{*}{ Treatment } & \multirow{2}{*}{$\begin{array}{c}\mathrm{pH} \\
(\mathrm{KCl})\end{array}$} & \multirow{2}{*}{$\begin{array}{c}\mathrm{pH} \\
\left(\mathrm{H}_{2} \mathrm{O}\right)\end{array}$} & \multirow{2}{*}{$\begin{array}{l}\mathrm{N} \\
\%\end{array}$} & $\mathrm{NH}_{4}^{+}$ & $\mathrm{NO}_{3}{ }^{-}$ & $\mathrm{P}$ & $\mathrm{K}$ & \multirow{2}{*}{$\begin{array}{c}\mathrm{Ca} \\
\mathrm{g} \mathrm{kg}^{-1}\end{array}$} & \multirow{2}{*}{$\begin{array}{c}\mathrm{Mg} \\
\mathrm{mg} \mathrm{kg}^{-1}\end{array}$} \\
\hline & & & & \multicolumn{4}{|c|}{$\mathrm{mg} \mathrm{kg}^{-1}$} & & \\
\hline Rhizobium & $4.53^{\mathrm{d}}$ & $5.10^{\mathrm{d}}$ & 0.18 & $15.7^{\mathrm{c}}$ & $110.8^{\mathrm{b}}$ & $22.1^{\text {cd }}$ & $105.1^{\mathrm{b}}$ & $2.50^{\mathrm{e}}$ & $261^{2}$ \\
\hline Rhizobium $3 \mathrm{tha}^{-1} \mathrm{CaCO}_{3} \mathrm{NPK}_{1 / 2}$ & $5.92^{\mathrm{b}}$ & $6.25^{\mathrm{b}}$ & 0.18 & $18.0^{\mathrm{abc}}$ & $118.4^{\mathrm{ab}}$ & $39.8^{\mathrm{a}}$ & $121.4^{\mathrm{b}}$ & $3.37^{\mathrm{c}}$ & $249^{\mathrm{ab}}$ \\
\hline Rbizobium $6 \mathrm{tha}^{-1} \mathrm{CaCO}_{3} \mathrm{NPK}_{1 / 2}$ & $6.67^{\mathrm{a}}$ & $6.95^{\mathrm{a}}$ & 0.18 & $18.1^{\mathrm{ab}}$ & $105.0^{\mathrm{b}}$ & $42.9^{\mathrm{a}}$ & $114.9^{\mathrm{b}}$ & $4.23^{\mathrm{b}}$ & $242^{\mathrm{ab}}$ \\
\hline Rbizobium $9 \mathrm{tha}^{-1} \mathrm{CaCO}_{3} \mathrm{NPK}_{1 / 2}$ & $6.76^{a}$ & $6.94^{\mathrm{a}}$ & 0.18 & $19.2^{\mathrm{a}}$ & $100.3^{b}$ & $42.9^{a}$ & $117.0^{\mathrm{b}}$ & $4.69^{\mathrm{a}}$ & $224^{\mathrm{bc}}$ \\
\hline Rhizobium Zeolite & $4.87^{\mathrm{c}}$ & $5.35^{\mathrm{c}}$ & 0.18 & $16.2^{\mathrm{bc}}$ & $57.75^{\mathrm{c}}$ & $22.5^{\mathrm{cd}}$ & $404.5^{\mathrm{a}}$ & $2.87^{\mathrm{d}}$ & $205^{c}$ \\
\hline NPK & $4.42^{\mathrm{de}}$ & $4.95^{\mathrm{e}}$ & 0.20 & $19.2^{\mathrm{a}}$ & $140.0^{\mathrm{a}}$ & $31.7^{\mathrm{b}}$ & $117.0^{\mathrm{b}}$ & $2.40^{\mathrm{e}}$ & $272^{\mathrm{a}}$ \\
\hline$\varnothing$ & $4.38^{\mathrm{e}}$ & $5.10^{\mathrm{d}}$ & 0.19 & $16.3^{\mathrm{bc}}$ & $144.1^{a}$ & $20.7^{\mathrm{d}}$ & $114.3^{\mathrm{b}}$ & $2.44^{\mathrm{e}}$ & $277^{\mathrm{a}}$ \\
\hline LSD & 0.11 & 0.11 & $0.13 \mathrm{~ns}$ & 2.5 & 14.0 & 4.90 & 15.63 & 0.32 & 25.4 \\
\hline
\end{tabular}

$\bar{\varnothing}$ - control (no inoculation and no fertilization); ns - statistically not significant; values followed by the sameletter in a column are not significantly different (Duncan test, $P<0.05)$

Table 3.Effects of inoculation and lime on micronutrient contents in soil

\begin{tabular}{|c|c|c|c|c|c|}
\hline \multirow{2}{*}{ Treatment } & $\mathrm{Fe}$ & $\mathrm{Mn}$ & $\mathrm{Cu}$ & $\mathrm{Zn}$ & B \\
\hline & \multicolumn{5}{|c|}{$\mathrm{mg} \mathrm{kg}^{-1}$} \\
\hline Rhizobium & $139.47^{\mathrm{a}}$ & $25.79^{b}$ & $2.89^{c}$ & $2.56^{\mathrm{b}}$ & $0.51^{\mathrm{a}}$ \\
\hline Rhizobium $3 \mathrm{t} \mathrm{ha}^{-1} \mathrm{CaCO}_{3} \mathrm{NPK}_{1 / 2}$ & $84.82^{c}$ & $13.31^{\mathrm{d}}$ & $2.05^{d}$ & $1.68^{\mathrm{d}}$ & $0.45^{\text {bc }}$ \\
\hline Rhizobium $6 \mathrm{tha}^{-1} \mathrm{CaCO}_{3} \mathrm{NPK}_{1 / 2}$ & $71.91^{\mathrm{c}}$ & $9.71^{\mathrm{d}}$ & $1.80^{\mathrm{e}}$ & $1.30^{\mathrm{e}}$ & $0.37^{\mathrm{d}}$ \\
\hline Rhizobium $9 \mathrm{t} \mathrm{ha}^{-1} \mathrm{CaCO}_{3} \mathrm{NPK}_{1 / 2}$ & $101.29^{c}$ & $9.87^{\mathrm{d}}$ & $2.01^{\mathrm{de}}$ & $1.11^{\mathrm{e}}$ & $0.32^{\mathrm{e}}$ \\
\hline Rhizobium Zeolite & $122.06^{\mathrm{b}}$ & $22.04^{\mathrm{c}}$ & $2.13^{\mathrm{d}}$ & $2.15^{\mathrm{c}}$ & $0.46^{\mathrm{b}}$ \\
\hline NPK & $151.55^{\mathrm{a}}$ & $30.89^{a}$ & $3.67^{\mathrm{a}}$ & $3.31^{\mathrm{a}}$ & $0.44^{\mathrm{bc}}$ \\
\hline$\varnothing$ & $142.92^{\mathrm{a}}$ & $26.31^{\mathrm{b}}$ & $2.46^{c}$ & $2.74^{\mathrm{b}}$ & $0.40^{\text {cd }}$ \\
\hline LSD & 15.07 & 3.64 & 0.247 & 0.369 & 0.046 \\
\hline
\end{tabular}

Table 4.Effects of inoculation and lime on shoot dryweight (SDW) and macronutrient contents in red clover plants (\% of dry weight)

\begin{tabular}{|c|c|c|c|c|c|c|c|c|c|c|c|c|}
\hline \multirow{3}{*}{ Treatment } & \multirow{2}{*}{\multicolumn{2}{|c|}{$\begin{array}{c}\text { SDW } \\
\text { mg plant }^{-1}\end{array}$}} & \multirow{2}{*}{\multicolumn{2}{|c|}{$\mathrm{N}$}} & \multicolumn{2}{|c|}{$\mathrm{P}$} & \multicolumn{2}{|c|}{$\mathrm{K}$} & \multicolumn{2}{|c|}{$\mathrm{Ca}$} & \multicolumn{2}{|c|}{$\mathrm{Mg}$} \\
\hline & & & & & & & & & & & & \\
\hline & $1^{\text {st }}$ & $2^{\text {nd }}$ & $1^{\mathrm{st}}$ & $2^{\text {nd }}$ & $1^{\text {st }}$ & $2^{\text {nd }}$ & $1^{\text {st }}$ & $2^{\text {nd }}$ & $1^{\mathrm{st}}$ & $2^{\text {nd }}$ & $1^{\text {st }}$ & $2^{\text {nd }}$ \\
\hline Rhizobium & $83.4^{\mathrm{cd}}$ & $392.8^{\mathrm{b}}$ & $4.48^{\mathrm{a}}$ & $3.42^{\mathrm{b}}$ & $0.17^{\mathrm{b}}$ & $0.22^{b c}$ & $3.00^{\mathrm{b}}$ & $2.38^{\mathrm{c}}$ & $1.85^{\mathrm{bc}}$ & $1.84^{\mathrm{a}}$ & $0.66^{\mathrm{a}}$ & $0.72^{\mathrm{a}}$ \\
\hline Rhizobium $3 \mathrm{t} \mathrm{ha}^{-1} \mathrm{CaCO}_{3} \mathrm{NPK}_{1 / 2}$ & $245.5^{\mathrm{a}}$ & $416.2^{b}$ & $2.81^{\mathrm{c}}$ & $3.29^{\mathrm{b}}$ & $0.24^{\mathrm{a}}$ & $0.17^{\mathrm{d}}$ & $2.67^{\mathrm{c}}$ & $2.15^{\mathrm{cd}}$ & $1.68^{d}$ & $1.85^{\mathrm{a}}$ & $0.52^{\text {cd }}$ & $0.64^{\mathrm{b}}$ \\
\hline Rhizobium $6 \mathrm{tha}^{-1} \mathrm{CaCO}_{3} \mathrm{NPK}_{1 / 2}$ & $225.2^{\mathrm{ab}}$ & $515.0^{\mathrm{a}}$ & $3.50^{\mathrm{b}}$ & $3.08^{\mathrm{b}}$ & $0.23^{\mathrm{a}}$ & $0.17^{\mathrm{d}}$ & $2.63^{c}$ & $1.82^{\mathrm{d}}$ & $1.64^{\mathrm{d}}$ & $1.94^{\mathrm{a}}$ & $0.58^{\mathrm{bc}}$ & $0.67^{\mathrm{b}}$ \\
\hline Rhizobium $9 \mathrm{t} \mathrm{ha}^{-1} \mathrm{CaCO}_{3} \mathrm{NPK}_{1 / 2}$ & $199.9^{\mathrm{b}}$ & $462.7^{\mathrm{ab}}$ & $3.68^{\mathrm{b}}$ & $2.67^{c}$ & $0.20^{\mathrm{a}}$ & $0.19^{\text {cd }}$ & $2.64^{c}$ & $1.82^{\mathrm{d}}$ & $1.76^{\mathrm{cd}}$ & $1.88^{\mathrm{a}}$ & $0.59^{\mathrm{b}}$ & $0.70^{\mathrm{a}}$ \\
\hline Rhizobium Zeolite & $196.6^{\mathrm{b}}$ & $417.0^{\mathrm{b}}$ & $3.12^{\mathrm{bc}}$ & $3.12^{\mathrm{b}}$ & $0.20^{\mathrm{a}}$ & $0.20^{\mathrm{cd}}$ & $2.92^{\mathrm{bc}}$ & $2.92^{\mathrm{ab}}$ & $1.46^{\mathrm{e}}$ & $1.50^{\mathrm{b}}$ & $0.38^{\mathrm{e}}$ & $0.39^{d}$ \\
\hline NPK & $91.8^{\mathrm{c}}$ & $259.7^{c}$ & $3.47^{\mathrm{b}}$ & $4.20^{\mathrm{a}}$ & $0.19^{\mathrm{a}}$ & $0.26^{\mathrm{ab}}$ & $3.62^{\mathrm{a}}$ & $3.08^{\mathrm{a}}$ & $1.91^{\mathrm{b}}$ & $1.86^{\mathrm{a}}$ & $0.51^{\mathrm{d}}$ & $0.62^{c}$ \\
\hline$\varnothing$ & $47.3^{\mathrm{d}}$ & $139.0^{\mathrm{d}}$ & $3.63^{\mathrm{b}}$ & $4.10^{\mathrm{a}}$ & $0.22^{\mathrm{a}}$ & $0.27^{\mathrm{a}}$ & $3.13^{\mathrm{b}}$ & $2.59^{b c}$ & $2.05^{\mathrm{a}}$ & $1.77^{\mathrm{a}}$ & $0.50^{\mathrm{d}}$ & $0.70^{\mathrm{a}}$ \\
\hline LSD & 37.29 & 65.96 & 0.39 & 0.41 & 0.03 & 0.04 & 0.20 & 0.42 & 0.12 & 0.23 & 0.06 & 0.03 \\
\hline
\end{tabular}

\section{Mineral composition of red clover plants}

The content of all macro and micronutrients (\% of dry weight and $\mathrm{mg} \mathrm{kg}^{-1}$, respectively) varied significantly between treatments, and it was either decreased or increased in respect to control (Table 4 and 5). In contrast to nutrient contents, the total nutrient uptake of all macro and micronutrients (mg plant ${ }^{1}$, data not shown) in all treatments was significantly increased in respect to control as the result of high shoot dry weight increase.

\section{Macronutrient contents in red clover plants}

In all treatments in both cuts, macronutrient contents, $\mathrm{N}, \mathrm{P}$, $\mathrm{K}, \mathrm{Ca}$ and $\mathrm{Mg}$ in red clover plants (Table 4), were above the critical level for macronutrient deficiency (Fairey, 1988), and mainly between adequate ranges for red clover (Bergmann, 1992), except low P content and elevated Mg content in some treatments.

Nitrogen content in plants varied between 2.67 and $4.48 \%$ of dry matter and it was in the range $\left(23.4-47.0 \mathrm{~g} \mathrm{~kg}^{-1}\right.$ dry matter) published by Spedding and Diekmahns (1972). In the first cut, the highest $\mathrm{N}$ content in plants was in the treatment with Rhizobium (4.48\%), due to nitrogen fixation, while in the second cut it was in NPK treatment (4.2\%), as a result of N mineral fertilization (Table 4). Nitrogen content in plants was in negative correlation with SDW in both cuts $(r=-0.610 ; r=-0.887)$. In all treatments in the second cut (except NPK), $\mathrm{N}$ content was lower compared to the control. However, these treatments showed higher SDW and total $\mathrm{N}$ uptake in plants $\left(\mathrm{mg} \mathrm{plant}^{-1}\right)$ was always higher in respect to control, indicating $\mathrm{N}_{2}$ fixation in inoculated plants.

According to Bergmann (1992), P content in red clover of $0.17-0.27 \%$ was low (0.3-0.6\% adequate range), but among or close to the values given by Fairey (1988) (0.2-0.4\%), and above the critical level of $0.15 \%$. Phosphorus content in plants in the first cut decreased in the Rhizobium treatment compared to control, while in the second cut, $\mathrm{P}$ content significantly decreased in all treatments (except in NPK treatment), regardless of the P increase in the soil in lime treatments (Table2).

Content of $\mathrm{K}$ in plants was optimal (1.8-3\%; Bergmann, 1992) except in the first cut in plants with NPK fertilization (3.6\%) and control (3.1), where it was high. In the treatments with Rhizobium and zeolite + Rhizobium, there were no changes in $\mathrm{K}$ content in plants despite the $\mathrm{K}$ increase in soil. Lime 
Table 5. Effects of inoculation and lime on micronutrient contents $\left(\mathrm{mg} \mathrm{kg}^{-1}\right)$ in red clover plants

\begin{tabular}{|c|c|c|c|c|c|c|c|c|c|c|}
\hline \multirow{2}{*}{ Treatment } & \multicolumn{2}{|c|}{$\mathrm{Fe}$} & \multicolumn{2}{|c|}{ Mn } & \multicolumn{2}{|c|}{$\mathrm{Cu}$} & \multicolumn{2}{|c|}{$\mathrm{Zn}$} & \multicolumn{2}{|c|}{ B } \\
\hline & $1^{\mathrm{st}}$ & $2^{\text {nd }}$ & $1^{\text {st }}$ & $2^{\text {nd }}$ & $1^{\mathrm{st}}$ & $2^{\text {nd }}$ & $1^{\mathrm{st}}$ & $2^{\text {nd }}$ & $1^{\mathrm{st}}$ & $2^{\text {nd }}$ \\
\hline Rhizobium & $855^{a}$ & $1250^{\mathrm{a}}$ & $107^{\mathrm{a}}$ & $123^{a}$ & $30.06^{\mathrm{a}}$ & $15.52^{\mathrm{bc}}$ & $68.92^{a}$ & $68.86^{a}$ & $25.60^{a}$ & 18.03 \\
\hline Rhizobium $3 \mathrm{t} \mathrm{ha}^{-1} \mathrm{CaCO}_{3} \mathrm{NPK}_{1 / 2}$ & $249^{c}$ & $965^{b}$ & $83^{\mathrm{bc}}$ & $92^{\mathrm{b}}$ & $14.74^{\mathrm{bc}}$ & $16.67^{\mathrm{bc}}$ & $61.60^{\mathrm{ab}}$ & $68.62^{\mathrm{a}}$ & $24.93^{\mathrm{a}}$ & 20.54 \\
\hline Rhizobium $6 \mathrm{t} \mathrm{ha}^{-1} \mathrm{CaCO}_{3} \mathrm{NPK}_{1 / 2}$ & $366^{\mathrm{b}}$ & $338^{\mathrm{d}}$ & $73^{\mathrm{d}}$ & $62^{\mathrm{d}}$ & $14.19^{\mathrm{bc}}$ & $13.85^{\mathrm{c}}$ & $56.20^{\mathrm{b}}$ & $56.48^{b}$ & $20.82^{\mathrm{b}}$ & 18.12 \\
\hline Rhizobium 9 t ha $^{-1} \mathrm{CaCO}_{3} \mathrm{NPK}_{1 / 2}$ & $255^{\mathrm{c}}$ & $754^{\mathrm{c}}$ & $75^{d}$ & $69^{\mathrm{cd}}$ & $14.27^{\mathrm{bc}}$ & $17.61^{\mathrm{ab}}$ & $56.88^{b}$ & $64.00^{\mathrm{a}}$ & $21.18^{\mathrm{b}}$ & 20.53 \\
\hline Rhizobium Zeolite & $230^{c}$ & $919^{\mathrm{b}}$ & $76^{\mathrm{cd}}$ & $81^{\mathrm{bc}}$ & $12.82^{\mathrm{bc}}$ & $16.01^{b c}$ & $55.72^{\mathrm{b}}$ & $64.70^{\mathrm{a}}$ & $20.48^{\mathrm{b}}$ & 17.06 \\
\hline NPK & $197^{c}$ & $312^{\mathrm{d}}$ & $89^{\mathrm{b}}$ & $94^{\mathrm{b}}$ & $12.24^{\mathrm{c}}$ & $20.04^{a}$ & $62.02^{\mathrm{ab}}$ & $70.00^{a}$ & $24.50^{a}$ & 20.05 \\
\hline$\varnothing$ & $354^{b}$ & $364^{d}$ & $100^{a}$ & $86^{\mathrm{b}}$ & $15.92^{\mathrm{b}}$ & $16.61^{b c}$ & $69.34^{\mathrm{a}}$ & $69.30^{\mathrm{a}}$ & $25.45^{\mathrm{a}}$ & 20.76 \\
\hline LSD & 70 & 101 & 7.4 & 12.4 & 2.08 & 2.64 & 8.48 & 5.67 & 1.53 & $2.61 \mathrm{~ns}$ \\
\hline
\end{tabular}

$\varnothing$-Control (no inoculation and no fertilization); ns - statistically not significant; values followed by the same letter in a column are not significantly different $(P<0.05) ; 1^{\text {st }} c u t, 2^{\text {nd }}$ cut

application in both cuts decreased $\mathrm{K}$ content in plants, while $\mathrm{K}$ content in plants significantly increased after NPK fertilization.

In all treatments $\mathrm{Ca}$ content was optimal, between 1-2\% comparing to Bergmann (1992) findings. In the first cut in all treatments, including lime treatments, $\mathrm{Ca}$ content significantly decreased compared to the control, while there were no differences in the second cut.

Higher content of $\mathrm{Mg}$ in both cuts, considering adequate range being between $0.25-0.60 \%$ (Bergmann, 1992), in all treatments (except zeolite) was detected (Table 4). In the first cut, in the treatments with Rhizobium as well as with lime, $\mathrm{Mg}$ content significantly increased compared to control. However, Mg content was lower in lime treatments in respect to Rhizobium alone. In treatment with zeolite + Rhizobium, $\mathrm{Ca}$ and $\mathrm{Mg}$ contents were significantly lower compared to other treatments.

In general, the macronutrient contents did not follow the increase in SDW (plant growth) in most of the treatments. Moreover, there were negative correlations between contents of some macronutrients and SDW in one or both cuts: $\mathrm{N}$ and $\mathrm{K}$ in both cuts, P and Ca in the first cuts (data not shown).

\section{Micronutrient contentsin red dloverplants}

The high Fe contents in plants, above $250 \mathrm{mg} \mathrm{kg}^{-1}$, or even toxic, $>500 \mathrm{mg} \mathrm{kg}^{-1}$, (Bergmann, 1992), were obtained mainly in the second cut in all treatments (Table 5). The most significant changes in Fe content were under Rhizobium inoculation, where Fe content increased 2.4 to 3.4 fold in respect to control in two cuts. In the treatments with lime and Rhizobium, Fe content was reduced compared to Rhizobium, but not completely and without a clear lime rate effect, in contrast to Fe content reduction in soil.

In all treatments in both cuts, $\mathrm{Mn}$ (except in Rhizobium treatment), and $\mathrm{Zn}$ contents in plants were among adequate ranges (35-100; 25-70 mg kg ${ }^{-1}$ respectively, Bergmann, 1992), while Cu content was elevated in the second cut $\left(7-15 \mathrm{mg} \mathrm{kg}^{-1}\right.$, Bergmann, 1992) (Table 5). The B content was above the critical level $(15 \mathrm{mg}$ $\mathrm{kg}^{-1}$; Fairey, 1988) in all treatments, and in the first cut at sufficient level (20-60 $\mathrm{mg} \mathrm{kg}^{-1}$; Neubert et al., 1970), but in the second cut it was somewhat lower. Rhizobium treatment increased $\mathrm{Mn}$ and $\mathrm{Cu}$ contents (in the first cut), but did not influence $Z n$ and $B$ contents in plants, compared to the control. Depending on the cut and the lime rate applied, in some treatments with lime and Rbizobium together, adecrease was noted in $\mathrm{Mn}, \mathrm{Cu}, \mathrm{Zn}$ and $\mathrm{B}$ contents (Table 5).

\section{Discussion}

Soil microorganisms are very important in the biogeochemical cycles of inorganic and organic nutrients in the soil and in the maintenance of soil health and quality (Jeffries et al., 2003). It has been reported that plant growth promoting rhizobacteria including rhizobia can influence the chemistry of soil nutrients in many ways and enhance nutrient uptake by plants (Dey et al., 2004; Saharan and Nehra, 2001). Rhizobium inoculation increased the soil $\mathrm{pH}$ and the availability of $\mathrm{Ca}$ and $\mathrm{Na}$ (but not $\mathrm{K}$ and $\mathrm{P}$ ) and micronutrients ( $\mathrm{Fe}, \mathrm{Cu}, \mathrm{Zn}$ and $\mathrm{Mn}$ ) in the rhizosphere of common bean (Bambara and Ndakidemi, 2010). In the presented study Rbizobium inoculation did not change soil $\mathrm{pH}$ or content of available macro and micronutrients, except the $\mathrm{B}$ content in the red clover rhizosphere. These differences can be the result of a quite higher initial soil pH (6.2 in $\mathrm{CaCl}_{2}$ ) in the previous study, compared to our research $\left(\mathrm{pH}_{\mathrm{KCl}} 4.38\right.$ or $\left.\mathrm{pH}_{\mathrm{H} 2 \mathrm{O}} 5.1\right)$. The changes in soil nutrient contents after liming were similar to the results published (Sikiric et al., 2011; Bailey, 1995; Dugalić et al., 2006).

Increased dry matter of red clover by Rhizobium inoculation and/or lime application obtained in this study corresponded to the previous researches (Jarak et al., 2006; Stevović et al., 2007). The positive effects of liming usually occur through amelioration of $\mathrm{Al}$ and $\mathrm{Mn}$ toxicity and/or alleviation of $\mathrm{Ca}$ deficiency (Haynes and Naidu, 1998). Lime-induced positive response in dry matter yield was greater and more immediate at sites where $\mathrm{pH}$ was below 5.3 (Fystro and Bakken, 2005) which was also the case in our study. Although higher yield was obtained with the application of $6 \mathrm{th}^{-1}$ lime and Rhizobium, it is cheaper to use inoculation only with satisfactory yield, particularly since the good lime effects fade in the second and third year after its application (Stevović et al., 2007).

As previously mentioned, Rhizobium inoculation increased nutrient uptake (P, K, Mg, S, Na, Fe, Cu, Zn, Mn and B) in numerous leguminous species; peanut, common bean, cowpea, chickpea and soybean (Howell 1987; Peix et al., 2001; Makoi $e t$ al., 2013; Ndakidemi et al., 2011; Belane et al., 2014; Tairo and Ndakidemi, 2014a). In these studies the total nutrient uptake in plants ( $\mathrm{mg} \mathrm{plant}^{-1}$ ) were mainly considered, but in the study by Belane et al. (2014) the nutrient concentrations were also increased after inoculation. In our study, the total nutrient uptake of all macro and microelements was also higher in all treatments in respect to control.

On the other hand, the inoculation with Rhizobium significantly increased contents of only two macronutrients in the first cut, $\mathrm{N}$ and $\mathrm{Mg}$ (compared to the control); contents of $\mathrm{K}$ and $\mathrm{Ca}$ did not change under inoculation, while $\mathrm{P}$ content even decreased in both cuts. Application of lime and Rhizobium together decreased the contents of $\mathrm{P}, \mathrm{K}$ and $\mathrm{Mg}$ in plants (in respect to control or Rhizobium alone). 
558

The increased $\mathrm{N}$ content in plants (\% of dry weight) in the first cut is the result of $\mathrm{N}_{2}$ fixation, and the total $\mathrm{N}$ content in plants (mg plant ${ }^{-1}$ ) of all treatments in both cuts was higher compared to control. Increased plant growth and high dry matter production (3 fold higher over control) caused the dilution effect of $\mathrm{N}$ and its decrease in plants of the treatments with higher SDW (Jarrell and Beverly, 1981; Timmer, 1991). Consequently, $\mathrm{N}$ content is negatively correlated with SDW, which was also found for some other nutrients in this and previous studies (Timmer, 1991; Imo, 2012).

After liming, the available $\mathrm{P}$ content in soil increased, since the increase in $\mathrm{pH}$ influenced the release of one part of bound $\mathrm{P}$ from Al- and Fe-phosphate in acid soils (Dugalić et al., 2006; Sikiric et al., 2011). Despite this increase, the P content in plants in the second cut decreased. Fageria et al. (1995) reported that increasing levels of lime tended to reduce $\mathrm{P}$ uptake, while lower $\mathrm{P}$ content in leaves could be caused by the antagonism between $\mathrm{P}$ and $\mathrm{Ca}$ (Jaravan and Poldma, 2004). In addition, as ryegrass developed and dry mass accumulation increased, phosphorus tissue content decreased due to the dilution effect (Mazza et al., 2012). Therefore the $P$ fertilization should be considered in red clover cultivation in very acid soils.

Lime application in both cuts, decreased $\mathrm{K}$ content in plants, possibly due to the antagonism in $\mathrm{Ca}$ and $\mathrm{K}$ uptake from soil solution (Jakobsen, 1993; Weis, 2009) and significant increase in SDW.

The unexpected decrease in $\mathrm{Ca}$ in the first cut in lime treatments was probably influenced by the short period to the first cut, and very rapid plant growth, together with relatively slow Ca uptake and transport (Reid and Horvath, 1980; Sonneveld and Voogt, 2009). The lack of differences in Ca concentration in plants between limed and unlimed plots was also noticed in some researches (Fystro and Bakken, 2005; Viade et al.,2011).

Higher contents of $\mathrm{Mg}$ in both cuts could be the result of high $\mathrm{Mg}$ content in soil and the tendency of red clover to uptake Mg easily (Loide, 2004). In the first cut, in the treatments with Rhizobium as well as with lime, $\mathrm{Mg}$ content significantly increased compared to control. However, $\mathrm{Mg}$ content was lower in lime treatments in respect to Rhizobium alone, which could be the result of the antagonism between $\mathrm{Ca}$ and $\mathrm{Mg}$ (Jakobsen, 1993).

In treatment with zeolite + Rhizobium, $\mathrm{Ca}$ and $\mathrm{Mg}$ contents were significantly lower compared to other treatments, possibly due to basic zeolite cations ( $\mathrm{Ca}, \mathrm{Mg}, \mathrm{Na}$ and $\mathrm{K}$ ) and the antagonistic relationship in $\mathrm{Ca} / \mathrm{K}$ and $\mathrm{Mg} / \mathrm{K}$ uptake, since high $\mathrm{K}$ content in soil was detected.

Rhizobium treatment increased $\mathrm{Fe}, \mathrm{Mn}$ and $\mathrm{Cu}$ contents (in the first cut), but did not influence $\mathrm{Zn}$ and $\mathrm{B}$ contents in plants, compared to the control. The most visible increase was in $\mathrm{Fe}$ content. Significant increase of Fe after Rhizobium inoculation in common bean and red clover was detected in previous studies and it is considered that microbes may favour plant $\mathrm{Fe}$ acquisition by producing siderophores and auxins (Jin et al., 2006; Ndakidemi et al., 2011). Siderophores are chelators with a high affinity for $\mathrm{Fe}^{3+}$, and many $\mathrm{Fe}^{3+}$-siderophore chelates are source of available Fe for plants, while auxin generation triggers the enhancement of Fe uptake capacity in plants, by enhancing root acquisition area and the activity of ferric chelate reductase (Jin et al., 2006; Jin et al., 2014). The R. leguminosarum bv. trifolii strain 459 used in this study apart from nitrogen-fixing ability, showed significant auxin production, as well as phosphate solubilization in in vitro conditions, however it is difficult to connect these traits with the changes induced in red clover nutrient contents without additional researches. In our study, in the treatments with lime and Rhizobium, Fe content was reduced compared to Rhizobium, but not completely and without clear lime rate effect, in contrast to Fe content reduction in soil. In previous studies, a correlation between overall Fe content in plants and $\mathrm{Fe}$ concentration in the soil was not established (DeKock, 1981).

Depending on the cut and the lime rate applied, in some treatments with lime and Rhizobium together, a decrease was noted in $\mathrm{Mn}, \mathrm{Cu}, \mathrm{Zn}$ and $\mathrm{B}$ contents. This decrease in micronutrient contents $(\mathrm{Mn}, \mathrm{Cu}, \mathrm{Zn}$ and $\mathrm{B})$, in plants after liming, is in agreement with previous reports (Fageria et al., 1995; Lalljee and Facknath, 2001). The decrease in micronutrient contents was the consequence of $\mathrm{pH}$ increase after liming or zeolite application, which decreases solubility of micronutrients in soil and the antagonism between particular ions ( $\mathrm{Ca}$ and $\mathrm{Mn}$ ) (Fageria et al., 1995).

\section{Conclusions}

Inoculation of red clover with Rhizobium increased plant growth in very acid soil, but lime application together with Rhizobium provided higher shoot dry weight. The uptake of all nutrients (N, P, K, Ca, Mg, Fe, Mn, Cu, Zn, B) in plants increased with Rhizobium and lime applications, while the contents of particular macro and micronutrients depended on the treatment applied, and were mainly in the adequate ranges for red clover. The $\mathrm{P}$ content in plants remained low, despite its increase in soil after lime application. In addition, content of B in plants was somewhat lower, although it was the only nutrient increased in soil by Rhizobium inoculation. In contrast, Rhizobium inoculation induced the biggest increase in $\mathrm{Fe}$ content, which was increased few times. To achieve proper growth and acceptable mineral composition of red clover under acid soils rhizobial inoculation may be useful.

\section{Acknowledgements}

This research was supported by the Ministry of Education and Science and Technological Development of the Republic of Serbia, Project TR37006.

\section{References}

Antoun H, Beauchamp CJ, Goussard N, Chabot R, Lalande R (1998). Potential of Rhizobium and Bradyrbizobium species as plant growth promoting rhizobacteria on non-legumes: Effects on radishes (Raphanussativus L.). Plant and Soil 204:57-67.

Bailey JS (1995). Liming and nitrogen efficiency: Some effects of increased calcium supply and increased soil $\mathrm{pH}$ on nitrogen recovery by perennial ryegrass. Communications in Soil Science and Plant Analysis 26:12331246.

Bambara S, Ndakidemi PA (2010). Changes in selected soil chemical properties in the rhizosphere of Phaseolus vulgaris L. supplied with Rhizobium inoculants, molybdenum and lime. Scientific Research and Essays 5:679-684. 
Belane AK, Pule-Meulenberg F, Makhubedu TI, Dakora FD (2014). Nitrogen fixation and symbiosis-induced accumulation of mineral nutrients by cowpea (Vigna unguiculata L. Walp.). Crop and Pasture Science 65:250-258.

Bergmann W (1992). Nutritional disorders of plants - development, visual and analytical diagnosis. Gustav Fischer Vela Jena, Stuttgart,New York.

Bremner JM (1965). Inorganic forms of nitrogen. In: Black CA, Evans DD, Ensminger LE, White JL, Clark FE (Eds). Methods of Soil Analysis. Part 2. Madison ASA andSSSA.

Chapman HD, Pratt PF (1961). Methods of Analysis for Soil, Plants and Water. Berkeley, University ofCalifornia.

De Kock PC (1981). Iron nutrition under conditions of stress. Journal of PlantNutrition 3:513-521.

Dey R, Pal KK, Bhatt DM, Chauhan SM (2004). Growth promotion and yield enhancement of peanut (Arachis hypogaea L.) by application of plant growth-promoting rhizobacteria. Microbiological Research 159:371-394.

Dible WT, Truog E, Berger KC (1954). Boron determination in soils and plants: Simplified curcumin procedure. Analytical Chemistry 26:418421.

Dugalić G, KatićS, Vasiljević S, Gajić B, Lazarević B, Đalović I (2006). Effects of liming on changes in pseudogley agrochemical properties and alfalfa yield. Acta Biologica Yugoslavica Zemljištei ibiljka 55:61-66.

Egnér H, Riehm H, Domingo WR (1960). Untersuchungen über die chemische Bodenanalyse als Grundlage für die Beurteilung des Nährstoffzustandes der Böden. II. Chemische Extraktionsmethoden zur Phosphor- und Kaliumbestimmung, [Studies concerning the chemical analysis of soils as background for soil nutrient assessment. II Chemical extracting methods to determinate the phosphorous and potassium content of soil] Kungliga Lantbrukshögskolans Annaler 26:199-215.

Fageria NK, Zimmermann FJP, Baligar VC (1995). Lime and phosphorus interactions on growth and nutrient uptake by upland rice, wheat, common bean, and corn in an oxisol. Journal of Plant Nutrition 18:2519-2532.

Fairey DT (1988). Red clover. Agriculture, Canada, Publication 1614/E Research Station, Beaverlodge, Alberta.

Fystro G, Bakken AK (2005). Soil reaction, yields and herbage element content as affected by lime applied on established leys in a multi-site field trial. The Journal of Agricultural Science 143:407-420.

Haynes RJ, Naidu R (1998). Influence of lime, fertilizer and manure applications on soil organic matter content and soil physical condition: A review. Nutrient Cycling in Agroecosystems 51:123-137.

Howell RK (1987). Rhizobium induced mineral uptake in peanut tissues. Journal of Plant Nutrition 6:1297-1305.

Imo M (2012). Analysis of Nutritional Interactions in Cropping Systems. In: Sharma P (Ed). Crop Production Technologies. ISBN: 978-953307-787-1, Retrieved 2015 November 28 from: http://www.intechopen.com/books/crop-productiontechnologies/analysis-of-nutritional-interactions-in-croppingsystems.

Jakobsen ST (1993). Interaction between plant nutrients: III. Antagonism between potassium, magnesium and calcium. Acta Agriculturae Scandinavica, Section B-Soil and Plant Science 43:1-5.
Jarak M, Djukic D, Colo J (2006). The effect of bacterization and liming in the production of red clover. Grassland Science in Europe 11:291-293.

Jaravan M, Poldma P (2004). Content of plant nutrients in vegetables depending on various lime materials used for neutralising bog peat. Agronomy Research 2:39-48.

Jarrell WM, Beverly RB (1981). The dilution effect in plant nutrition studies. Advancesin Agronomy 34:197-224.

Jeffries P, Gianinazzi S, Perotto S, Turnau K, Barea JM (2003). The contribution of arbuscular mycorrhizal fungi in sustainable maintenance of plant health and soil fertility. Biology and Fertility of Soils 37:1-16.

Jin CW, Ye YQ, Zheng SJ (2014). An underground tale: contribution of microbial activity to plant iron acquisition via ecological processes. Annals of Botany 113:7-18.

Jin CW, He YF, Tang CX, Wu P, Zheng SJ (2006). Mechanisms of microbially enhanced Fe acquisition in red clover (Trifolium pratense L.). Plant, Cell and Environment 29:888-897.

Makoi JH, Bambara S, Ndakidemi PA (2013). Rhizobium inoculation and the supply of molybdenum and lime affect the uptake of macroelements in common bean (P. vulgaris L.) plants. Australian Journal of Crop Science 7:784793.

Mazza LM, Motta ACV, Moraes AV, Fabiane MA, Fernando P, Oliveira RD (2012). Forage yield and quality on soil subjected to phosphorus rates in subtropical grassland of Brazil. Revista Brasileira de Zootecnia 41:1100-1109.

Lalljee B, Facknath S (2001). Effect of lime on nutrient content of soils, yield and nutrient content of potato and infestation by leafminers. In: Lalouette JA, Bachraz DY (Eds). Proceedings of The fifth annual meeting of agricultural scientists, Food and Agricultural Research Council2001 Reduit, Mauritius pp 139-147.

Lindstrom K, Myllyniemi H (1987). Sensitivity of red clover rhizobia to soil acidity factors in pure culture and in symbiosis. Plant and Soil 98:353362.

Loide V (2004). About the effect of the contents and ratios of soils available calcium, potassium magnesium in liming of acid soils. Agronomy Research 2:71-82.

Neubert P, Wrazidlo W, Vielemeyer HP, Hundt I, Gollmick Fr, Bergmann W (1970). Tables of Plant Analysis. Institute of Plant Nutrition, Jena.

Ndakidemi PA, Bambara S, Makoi JHJR (2011). Micronutrient uptake in common bean (Phaseolus vulgaris L.) as affected by Rhizobium inoculation, and the supply of molybdenum and lime. Plant OMICS 4:40-52.

Peix A, Rivas-Boyero AA, Mateos PF, Rodriguez-Barrueco C, MartínezMolina E, Velazquez E (2001). Growth promotion of chickpea and barley by a phosphate solubilizing strain ofMesorhizobium mediterraneum under growth chamber conditions. Soil Biology and Biochemistry 33:103-110.

Reid RL, Horvath DS (1980). Soil chemistry and mineral problems in farm livestock: a review. Animal Feed Science and Technology 15:95-167.

Saharan B, Nehra V (2001). Plant Growth Promoting Rhizobacteria: A Critical Review.LifeScience and Medicine Research 21:1-30.

Sikiric B, Cakmak D, Saljnikov E, Mrvic V, Jakovljevic M, Stajkovic O, Bogdanovic D (2011). Optimization of macroelement contents in raspberry leaves by liming in an extremely acid soil. Spanish Journal of 
560

Agricultural Research 9:329-337.

Soltanpour PN, Johnson GW, Workman SM, Jones JB Jr, Miller RO (1996). Inductively coupled plasma emission spectrometry and inductively coupled plasma mass spectrometry. In: Sparks DL (Ed). Methods ofSoil Analysis, Part 3. Madison, ASA and SSSA pp 91-139.

Sonneveld C, Voogt W (2009). Plant Nutrition of Greenhouse Crops. SpringerNetherlands.

Spedding CRW, Diekmahns EC (1972). Grasses and Legumes in British Agriculture. Bulletin No 49, Commonwealth Bureau of Pastures and Field Crops, Farnham Royal.

Stevović V, Đukić D, Đurović D, Mandić L (2007). Uticaj inokulacije semena i kalcifikacije zemljišta na prinos i kvalitet krme lucerke i crvene deteline [Influence of seed inoculation and liming on forage yield and quality of alfalfa and red clover]. Zbornik radova Instituta za ratarstvo i povitarstvo NoviSad 44:253-260.

Tairo EV, Ndakidemi PA (2014a). Macronutrients Uptake in Soybean as Affected by Bradyrhizobium japonicum Inoculation and Phosphorus (P) Supplements. American Journal of Plant Sciences 5:488-496.

Tairo EV, Ndakidemi PA (2014b). Micronutrients uptake in soybean (Glycine max L.) as affected by Bradyrbizobium japonicum inoculation and phosphorus (P) supplements. World Journal of Soil and Crop Sciences Research 1:1-9.

Taylor NL, Quesenberry KH (1996). Red clover science. Kluwer Academic Publishers, Dordrecht.
Timmer VR (1991). Interpretation of seedling analysis and visual symptoms. In: Van den Driessche R (Ed). Mineral Nutrition of Conifer Seedlings. CRC Press, Florida pp 113-134.

Thilakarathna RMMS, Papadopoulos YA, Rodd AV, Gunawardena AN, Fillmore SAE, Prithiviraj B (2012). Characterizing nitrogen transfer from red clover populations to companion bluegrass under field conditions. Canadian Journal of Plant Science 92: 1163-1173.

Vasiljević S, Mihailović V, Katić S, Mikić A, Karagić Đ (2010) Potencijal rodnosti sorti crvene deteline (Trifolium pratense L.) [Potential for yield in red clover (Trifolium pratense L.) varieties.]. Ratarstvo i povitarstvo 47:217-223.

Viade A, Fernandez-Marcos ML, Hernandez-Nistal J, Alvarez E (2011).Effect of particle size of limestone on $\mathrm{Ca}, \mathrm{Mg}$ and $\mathrm{K}$ contents in soil and in sward plants. Scientia Agricola 68:200-208.

Von Uexküll HR, Mutert E (1995). Global extent, development and economic impact of acid soils. Plant and Soil 171:1-15.

Warembourg FR, Lafont F, Fernandez MP (1997). Economy of symbiotically fixed nitrogen in red clover (Trifolium pratense L.). Annals ofBotany 80:515-523.

Weis W, Gruber A, Huber C, Göttlein A (2009). Element contents and storage in the above ground biomass of limed and unlimed Norway spruce trees at Höglwald. European Journal of Forest Research 128:437445. 